\title{
Sensitivity studies of different aerosol indirect effects in mixed-phase clouds
}

\author{
U. Lohmann ${ }^{1}$ and C. Hoose ${ }^{2}$ \\ ${ }^{1}$ Institute of Atmospheric and Climate Science, ETH Zurich, Switzerland \\ ${ }^{2}$ University of Oslo, Department of Geosciences, Oslo, Norway
}

Received: 6 June 2009 - Published in Atmos. Chem. Phys. Discuss.: 13 July 2009

Revised: 11 November 2009 - Accepted: 15 November 2009 - Published: 26 November 2009

\begin{abstract}
Aerosols affect the climate system by changing cloud characteristics. Using the global climate model ECHAM5-HAM, we investigate different aerosol effects on mixed-phase clouds: The glaciation effect, which refers to a more frequent glaciation due to anthropogenic aerosols, versus the de-activation effect, which suggests that ice nuclei become less effective because of an anthropogenic sulfate coating. The glaciation effect can partly offset the indirect aerosol effect on warm clouds and thus causes the total anthropogenic aerosol effect to be smaller. It is investigated by varying the parameterization for the Bergeron-Findeisen process and the threshold coating thickness of sulfate $\left(\mathrm{SO}_{4}\right.$-crit), which is required to convert an externally mixed aerosol particle into an internally mixed particle. Differences in the net radiation at the top-of-the-atmosphere due to anthropogenic aerosols between the different sensitivity studies amount up to $0.5 \mathrm{~W} \mathrm{~m}^{-2}$. This suggests that the investigated mixedphase processes have a major effect on the total anthropogenic aerosol effect.
\end{abstract}

\section{Introduction}

The interactions of aerosols with clouds is the largest source of uncertainty for estimating the total anthropogenic forcing since pre-industrial times (Forster et al., 2007). Anthropogenic aerosol particles such as sulfate and carbonaceous aerosols have substantially increased the global mean burden of aerosol particles from pre-industrial times to the

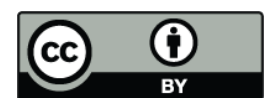

Correspondence to: U. Lohmann (ulrike.lohmann@env.ethz.ch) present-day. Aerosols can interact with clouds and precipitation by acting as cloud condensation or ice nuclei. The suite of possible impacts of aerosols through the modification of cloud properties is called indirect effects (Forster et al., 2007; Denman et al., 2007). The cloud albedo effect refers to the change in the radiative forcing at the top-ofthe-atmosphere caused by an enhancement in cloud albedo from anthropogenic aerosols that leads to more and smaller cloud droplets for a given cloud water content. Feedbacks due to the cloud lifetime effect, semi-direct effect or aerosol effects on mixed-phase and ice clouds can either enhance or reduce the cloud albedo effect. The cloud lifetime effect refers to the fact that the more and smaller cloud droplets, which form on the increased present-day aerosol concentrations, collide less efficiently. While cloud resolving models suggest that this could lead to either an increase or decrease in liquid water path (Ackerman et al., 2004; Sandu et al., 2008), global climate models (GCMs) generally predict an additional reflection of solar radiation due to the cloud lifetime effect (Lohmann and Feichter, 2005). The semidirect effect refers to an evaporation of cloud droplets due to the heating by absorbing aerosols (Hansen et al., 1997; Ramanathan et al., 2001). In GCMs it is normally smaller than the cloud albedo and cloud lifetime effect (Lohmann and Feichter, 2005). Aerosol effects on mixed-phase clouds are discussed in detail below.

Climate models estimate the sum of all anthropogenic aerosol effects (total indirect plus direct) to be $-1.2 \mathrm{~W} \mathrm{~m}^{-2}$ with a range from -0.2 to $-2.3 \mathrm{~W} \mathrm{~m}^{-2}$ in the change in the top-of-the-atmosphere net radiation since pre-industrial times (Denman et al., 2007), whereas inverse estimates constrain the indirect aerosol effect to be between -0.1 and $-1.7 \mathrm{~W} \mathrm{~m}^{-2}$ (Hegerl et al., 2007). 


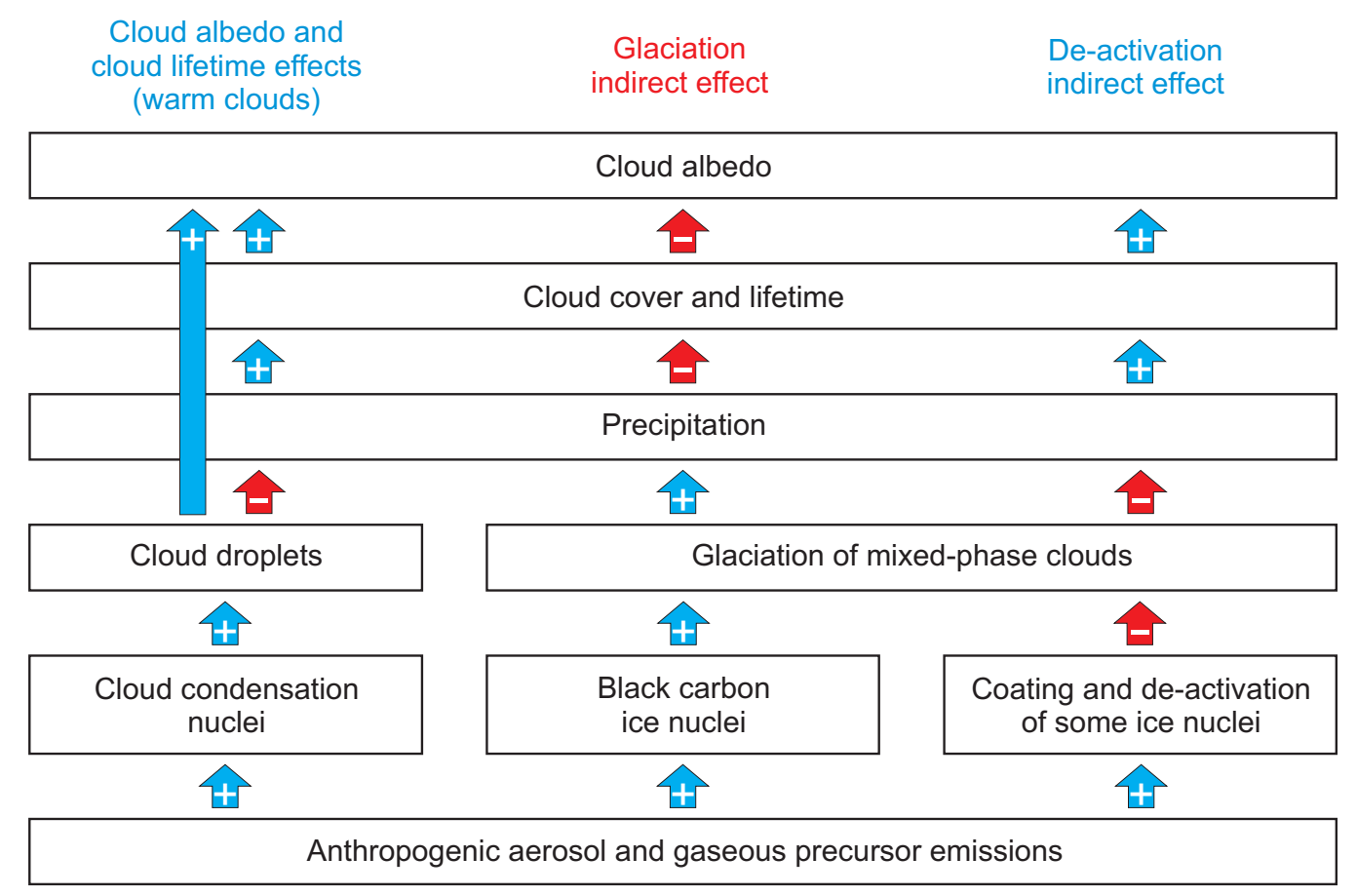

Fig. 1. Schematic of aerosol indirect effects in warm and mixed-phase stratiform clouds. Adapted from (Hoose et al., 2008b) with modifications.

Ice formation in clouds at temperatures above approximately $-35^{\circ} \mathrm{C}$ occurs by heterogeneous freezing, with the aid of ice nuclei (IN). IN are insoluble particles with crystalline structure, such as mineral dust, biological particles and soot (Pruppacher and Klett, 1997). Heterogeneous freezing can be initiated via collision of a supercooled cloud droplet and an IN (contact freezing) or from within a cloud droplet on an IN that is immersed in it. Soot particles are largely of anthropogenic origin, so anthropogenic activity may have introduced additional IN into the atmosphere. As shown in Fig. 1, such an increase in IN would lead to an anthropogenic increase in freezing and cloud glaciation, termed "glaciation effect" (Lohmann, 2002). Due to the difference in water vapor pressure over water and ice, these ice crystals can grow at the expense of water droplets via the BergeronFindeisen process. As the ice crystals grow in a highly supersaturated environment with respect to ice, they rapidly grow to precipitation size and sediment. This reduces the total cloud cover and allows more shortwave radiation to be absorbed in the Earth-Atmosphere system, which partly offsets the indirect effect on warm clouds.

If the glaciation effect prevails or not was found to be very sensitive to the assumption of the ice nucleation abilities and number concentrations of mineral dust and black carbon aerosols. If mineral dust is an efficient ice nucleus that commences freezing at rather warm temperatures, such as montmorillonite/illite, then contact freezing of black carbon (BC) is negligible and the indirect aerosol effect on warm clouds dominates. If, on the other hand, mineral dust is assumed to be composed of kaolinite, which is a worse ice nucleus than montmorillonite, the glaciation effect is present, and partly counteracts the shortwave indirect aerosol effect on warm clouds (Lohmann and Diehl, 2006). Similar results should be obtained if Asian dust were assumed instead of kaolinite as data by Field et al. (2006) compiled by Phillips et al. (2008) for freezing parameterizations showed that immersion freezing of droplets containing Asian dust is only initiated at $-29^{\circ} \mathrm{C}$. New data obtained within the AIDA cloud chamber (Connolly et al., 2009) suggest that immersion freezing on Arizona test dust, Saharan dust or Asian dust could commence at warmer or colder temperatures depending on the size of the dust aerosol than the temperature deduced for montmorillonite from the cloud chamber data used in Lohmann and Diehl (2006).

The glaciation effect in Lohmann and Diehl (2006) was deduced from the ECHAM4 global climate model (GCM) simulations that assumed aerosol particles to be externally mixed. When GCM simulations using the newer ECHAM5 GCM (Roeckner et al., 2003), which predicts the mixing state of aerosols and uses newer aerosol emissions (Stier et al., 2005), were evaluated in the same way by varying the mineralogical composition of the mineral dust aerosols, no glaciation effect was found. On the contrary, the aerosol effect on mixed-phase clouds had the same sign 
as the aerosol effect on warm clouds (Hoose et al., 2008b). This resulted because both carbonaceous and sulfate aerosols increased since pre-industrial times. The increase in sulfate caused more $\mathrm{BC}$ and dust aerosols to be internally mixed in the present-day climate than in pre-industrial times. Here internally mixed aerosols act as immersion nuclei whereas externally mixed aerosols act as contact nuclei.

Laboratory data that investigated contact versus immersion freezing showed that contact freezing commences at warmer temperatures (Shaw et al., 2005; Diehl et al., 2006). Thus, if in present times more dust aerosols are internally mixed immersion nuclei they are worse IN than in preindustrial times, where more of them acted as contact nuclei. This effect in essence corresponds to a de-activation of IN (Girard et al., 2004) ("de-activation effect") as also shown in Fig. 1. Rather than assuming that a sulfate coating de-activates the IN completely, the studies by Hoose et al. (2008b) and Storelvmo et al. (2008a) show a shift of the IN activation from contact nucleation to immersion nucleation. Note that the de-activation effect assumes that coatings are dominated by anthropogenic aerosols, such as sulfates and nitrates, which increased since pre-industrial times. If, on the other hand, coatings were dominated by biogenic secondary organic aerosols (SOA) and coatings by anthropogenic species were negligible, the de-activation effect would be negligible. The de-activation effect also assumes that coatings decrease the efficiency of IN, which may not be always true either. Lastly it assumes that contact freezing, although limited by collision rates, is in essence more efficient than condensation/immersion freezing. All these issues are still not solved and are subject to forthcoming research.

Lately more observational studies of heterogeneous freezing in the mixed-phase cloud regime, i.e. between temperatures of $-35^{\circ}$ and $0^{\circ} \mathrm{C}$ have become available. These include studies of the effects of trace gases on IN. For heterogeneous freezing on mineral dust in the deposition mode, it was found that ammonia increases its nucleation efficiency but exposure by sulfur dioxide and ozone does not seem to have an effect (Salam et al., 2008). On the other hand, a de-activation is also possible when physiochemical transformations on e.g. mineral dust surface reduce its efficiency as an IN (Baker and Peter, 2008). Eastwood et al. (2009) found that sulfuric acid coatings on kaolinite particles increased the relative humidity with respect to ice at which freezing commences by approximately $30 \%$. Likewise coatings with ammonium sulfate caused kaolinite particles to be poor IN at $245 \mathrm{~K}$. Similar findings were obtained in the LACIS cloud chamber by Niedermeier et al. (2009) for Arizona test dust for coatings with succinic acid, sulfuric acid and ammonium sulfate at temperatures between 233 and $241 \mathrm{~K}$. These two studies suggest a de-activation effect of sulfate coatings on mineral dust nuclei acting as deposition nuclei. However, given that dust in the LACIS chamber and in the ZINC chamber (Welti et al., 2009) initiates freezing at rather low temperatures that are close to homogeneous freezing, it is questionable how important coatings are. In summary, the de-activation effect would counteract the cloud glaciation effect, and which effect will dominate in any given case depends on the concentration of natural and anthropogenic IN and the amount of anthropogenic material available for IN coating.

In this paper we investigate under which conditions the glaciation or the de-activation effect dominate. In the context of our GCM this is controlled by assumptions about the transfer from the externally mixed to internally mixed aerosol modes and by the onset of the Bergeron-Findeisen process. Specifically, we vary the coating thickness of sulfate $\left(\mathrm{SO}_{4}\right.$-crit) that is required to convert an externally mixed aerosol particle into an internally mixed aerosol particle using the ECHAM5 GCM. We also investigate the contribution of thermophoresis to contact freezing, which could be of importance in subsaturated cloudy regions where the temperature gradient would favor collisions between a contact IN and an evaporating cloud droplet as evaluated by Phillips et al. (2007).

\section{Model description}

The version of ECHAM5 used in this study has been described in Lohmann et al. (2008). It includes the twomoment aerosol scheme HAM that predicts the aerosol mixing state in addition to the aerosol mass and number concentrations (Stier et al., 2005). The size-distribution is represented by a superposition of log-normal modes including the major global aerosol compounds sulfate, BC, organic carbon, sea salt and mineral dust.

The stratiform cloud scheme consists of prognostic equations for the water phases (vapor, liquid, solid), bulk cloud microphysics (Lohmann and Roeckner, 1996), and an empirical cloud cover scheme (Sundqvist et al., 1989). The microphysics scheme includes phase changes between the water components and precipitation processes (autoconversion, accretion, aggregation). Moreover, evaporation of rain and melting of snow are considered, as well as sedimentation of cloud ice. It also includes prognostic equations of the number concentrations of cloud droplets and ice crystals and has been coupled to the aerosol scheme HAM (Lohmann et al., 2007). It assumes that cirrus clouds form by homogeneous freezing of supercooled solution droplets (Lohmann et al., 2008), which is the dominant freezing mechanism for cirrus clouds (Kärcher and Ström, 2003).

We assume that internally mixed dust and BC aerosols act as immersion nuclei while externally mixed dust particles act as contact nuclei (Hoose et al., 2008b). The parameterizations of immersion and contact freezing are based on those described in Lohmann and Diehl (2006). In addition we now also account for contact freezing by thermophoresis as explained below. Mineral dust is supposed to have the freezing properties of illite/montmorillonite which is the dominant clay fraction (Hoose et al., 2008b). Note that contrary to 
earlier studies with ECHAM5-HAM we omit contact freezing by black carbon because it is rather uncertain.

For this study, we introduced contact freezing due to thermophoresis $Q_{\text {th }}$ in $\mathrm{kg} \mathrm{kg}^{-1} \mathrm{~s}^{-1}$ into ECHAM5-HAM following Cotton et al. (1986):

$Q_{\mathrm{th}}=\frac{4 \pi r_{l} q_{l}\left(N_{\mathrm{IN}}^{\mathrm{DU}} f_{t}^{\mathrm{DUa}}+N_{\mathrm{IN}}^{\mathrm{DUc}} f_{t}^{\mathrm{DUc}}\right) k_{a}\left(T_{\infty}-T\right)}{p \rho_{a}^{2}}$

Here $r_{l}$ is the cloud droplet radius, $q_{l}$ is the cloud liquid water mass mixing ratio, $N_{\mathrm{IN}}$ is the number of accumulation mode dust (DUa) and coarse mode dust (DUc) contact ice nuclei as given in Hoose et al. (2008b), $p$ is the atmospheric pressure, $\rho_{a}$ is the air density, $k_{a}$ is the thermal conductivity of air that depends on temperature following Pruppacher and Klett (1997), $\left(T_{\infty}-T\right)$ is the temperature difference between the environment and the surface of the cloud droplet. $f_{t}$ is an empirical function depending on the Knudsen number $\left(K_{n}=(7.37 T) /\left(2.88 \times 10^{5} p r_{\mathrm{ap}}\right)\right.$ in SI units $)$ and the thermal conductivity of the aerosols $\left(k_{\mathrm{ap}}\right)$. Here $r_{\text {ap }}$ is the wet radius of the aerosol particles that is obtained separately for each aerosol mode. Following Cotton et al. (1986) $f_{t}^{x}$ is given as:

$f_{t}^{x}=\frac{0.4\left[1+1.45 K_{n}^{x}+0.4 K_{n}^{x} \exp \left(-1 / K_{n}^{x}\right)\right]\left(k_{a}+2.5 K_{n}^{x} k_{\mathrm{ap}}^{x}\right)}{\left(1+3 K_{n}^{x}\right)\left(2 k_{a}+5 k_{\mathrm{ap}}^{x} K_{n}^{x}+k_{\mathrm{ap}}^{x}\right)}$

where $x$ refers to the different aerosol modes, DUa and DUc. Differently from Cotton et al. (1986) we use the aerosol thermal conductivity of $k_{\mathrm{ap}}^{\mathrm{DU}}=0.72 \mathrm{~J} \mathrm{~m}^{-1} \mathrm{~s}^{-1} \mathrm{~K}^{-1}$ for mineral dust (Seinfeld and Pandis, 1997).

Cotton et al. (1986) approximate the temperature difference $\left(T_{\infty}-T\right)$ as:

$T_{\infty}-T=\frac{\rho_{a} L_{v}\left[\left(d q_{i / d t}\right)_{\mathrm{vd}}+d q_{s / d t}\right]}{4 \pi N_{l} r_{l}}$

where $\left(d q_{i / d t}\right)_{\mathrm{vd}}$ is the growth of ice crystals due to vapor diffusion, $d q_{s / d t}$ is the change is saturation water vapor mixing ratio and $L_{v}$ is the latent heat of vaporization. Note that Eq. (3) can be positive and negative and thus can the freezing rate due to thermophoresis (Eq. 1).

In simulation $\mathrm{BF}$ we introduced a new parameterization for the onset of the Bergeron-Findeisen process following Korolev (2007) and Storelvmo et al. (2008b). The BergeronFindeisen process takes place when ice crystals grow at the expense of cloud droplets:

$e_{s}>e>e_{i}$

where $e$ is the actual vapor pressure, $e_{s}, e_{i}$ are the saturation vapor pressures with respect to water and ice. If Eq. (4) is fulfilled, cloud droplets will evaporate and provide a source of water vapor for depositional growth of ice crystals. The glaciation timescale with which this cloud glaciates depends on the ice crystal number concentration, ice water content and liquid water content. Following Korolev and Mazin (2003), Eq. (4) holds true if:

$w^{0}<w<w^{*}$

where $w$ is the updraft velocity. In our model $w$ is obtained as the sum of the grid mean vertical velocity $\bar{w}$ and a turbulent contribution expressed in terms of the turbulent kinetic energy (TKE) (Lohmann et al., 1999). TKE in turn is obtained from a prognostic equation described in Brinkop and Roeckner (1995). For stratiform clouds originating from detrainment of convective clouds also a contribution of the convectively available potential energy (CAPE) (Rogers and Yau, 1989) has been added:

$w=\left\{\begin{array}{l}\bar{w}+1.33 \sqrt{\mathrm{TKE}} \text { stratiform clouds } \\ \bar{w}+\sqrt{\mathrm{CAPE}}+1.33 \sqrt{\mathrm{TKE}} \text { convective clouds }\end{array}\right.$

Below $w^{0}$ ice crystals will sublimate, while above $w^{*}$ both cloud droplets and ice crystals will grow simultaneously. Simultaneous growth of cloud droplets and ice crystals is not possible in our model. Depending on temperature and the criterion for the Bergeron-Findeisen process in ECHAM5 either cloud droplets grow by condensation or evaporate and saturation with respect to water is assumed or ice crystals grow by deposition or sublimate and saturation with respect to ice is assumed. Nevertheless we could adopt the criterion $w<w^{*}$ for the Bergeron-Findeisen process. If $w<w^{*}$ and the temperature is between 0 and $-35^{\circ} \mathrm{C}$, we allow the Bergeron-Findeisen process, i.e. complete evaporation of all water droplets and depositional growth of the ice crystals. This process continues until $e=e_{i} . w^{*}$ is given as:

$w^{*}=\frac{e_{s}-e_{i}}{e_{i}} N_{i} \overline{r_{i}} \eta$

where $N_{i}$ is the ice crystal number concentration, $\overline{r_{i}}$ the mean volume radius of the ice particles and $\eta$ is a coefficient dependent on temperature and pressure (Korolev and Mazin, 2003).

The criterion $w<w^{*}$ replaces our previous simplified criterion for the Bergeron-Findeisen process, which was given as $e_{s}>e>e_{i}$ if a minimum ice water mixing ratio of $0.1 \mathrm{mg} / \mathrm{kg}$ was exceeded. A minimum ice water mixing ratio was chosen to ensure that some ice crystals were present.

Condensation of sulfate on dust and BC particles or coagulation with internally mixed particles can transfer insoluble $\mathrm{BC}$ and dust particles to the internally mixed aerosol modes. This transfer occurs for 1 monolayer of sulfate in the reference simulation Ref (Vignati et al., 2004). This parameter is highly uncertain and could be larger (Seinfeld and Pandis, 1997). Thus, we conduct sensitivity simulations in which $\mathrm{SO}_{4}$-crit, the threshold for considering $\mathrm{BC}$ and dust as internally mixed aerosols acting as immersion nuclei is set to 10 monolayers (simulations 10lay and BF-10lay; see Table 1). Externally mixed BC resides only in the Aitken mode 
Table 1. Sensitivity simulations.

\begin{tabular}{|c|c|}
\hline Simulation & Description \\
\hline Ref & $\begin{array}{l}\text { Nudged simulation for the year } 2000 \text { with ECHAM5-HAM coupled to the double-moment } \\
\text { cloud microphysics scheme for stratiform clouds. Differences to Lohmann et al. (2008) are } \\
\text { the incorporation of aerosol nucleation due to cosmic rays and organic vapors, a new water } \\
\text { uptake scheme, thermophoresis for contact freezing, omission of black carbon as a contact } \\
\text { nucleus and addition of a size-dependent below cloud scavenging routine. }\end{array}$ \\
\hline Clim & 10-year climatological simulation \\
\hline 10lay & $\begin{array}{l}\text { As simulation Ref, but requiring } 10 \text { monolayers of sulfate coating }\left(\mathrm{SO}_{4} \text {-crit) before }\right. \\
\text { externally mixed } \mathrm{BC} \text { and mineral dust particles are considered to be internally mixed }\end{array}$ \\
\hline $\mathrm{BF}$ & $\begin{array}{l}\text { As simulation Ref, but revised parameterization of the Bergeron-Findeisen process } \\
\text { (see text for details) }\end{array}$ \\
\hline NoThermo & As simulation Ref, but no contact freezing due to thermophoresis \\
\hline BF-10lay & $\begin{array}{l}\text { As simulation 10lay, but with the revised parameterization of the Bergeron-Findeisen } \\
\text { process }\end{array}$ \\
\hline E5-2008 & $\begin{array}{l}\text { Results from a 5-year climatological simulation with a previous version of ECHAM5-HAM } \\
\text { described in (Lohmann et al., 2008) assuming homogeneous freezing for cirrus formation }\end{array}$ \\
\hline
\end{tabular}

and mineral dust only in the accumulation and coarse modes (Vignati et al., 2004; Stier et al., 2005). Internally mixed BC can be found in the Aitken, accumulation and coarse mode. For the insoluble aerosols the modes are less relevant as there is no repartitioning into the larger insoluble modes. Upon emissions the number mean radius for $\mathrm{BC}$ is $30 \mathrm{~nm}$ for fossil fuel and bio-fuel emissions and $75 \mathrm{~nm}$ for vegetation fires. Thus there is a significant fraction of $\mathrm{BC}$ in the accumulation size range.

Another difference between the ECHAM version used in this study and that described in Lohmann et al. (2008) is that this version includes the aerosol-size dependent belowcloud scavenging by Croft et al. (2009). Previously, belowcloud scavenging by rain and snow in ECHAM5-HAM was simply a function of the aerosol mode, and then scaled by the rainfall and snowfall rate, respectively. Water uptake by aerosols following Petters and Kreidenweis (2007) is used in this version, which yields improved aerosol optical depths, in particular over the oceans, in comparison with an aerosol optical depth climatology based on an Aeronet/AEROCOM composite (D. O'Donnell, S. Kinne, personal communication, 2009). Also, the aerosol nucleation scheme is revised such that we now account for neutral and charged sulfuric acid/water aerosol nucleation (Kazil and Lovejoy, 2007), cluster activation that considers organic vapors as condensating agents in the sulphuric acid/water aerosol nucleation process (Kulmala et al., 2006) and ionization by galactic cosmic rays, which is a function of the decadal solar activity cycle (O’Brien, 2005).

\section{Set-up of the simulations}

The ECHAM5 simulations have been carried out in T42 horizontal resolution $\left(2.81^{\circ} \times 2.81^{\circ}\right)$ on 19 vertical levels with the model top at $10 \mathrm{hPa}$ and a timestep of $30 \mathrm{~min}$. All simulations used climatological sea surface temperature and seaice extent. Simulation Clim has been integrated for 10 years after a 3 months spin-up.

Simulation Ref is identical to simulation Clim except that nudging to the ECMWF ERA40 reanalysis data (Simmons and Gibson, 2000) for the year 2000 was applied (Table 1). We employ nudging for all simulations but Clim and the previous version E5-2008 (Lohmann et al., 2008) because we are interested in the partitioning of mineral dust between the internally and externally mixed modes, at constant emissions. As mineral dust emissions depend sensitively on the prevailing winds, small changes in meteorology that are common between simulations driven by climatological sea surface temperature and sea-ice extent could offset the coating effects that we are investigating in this study. Because nudging ensures that changes in meteorology are minimized between the different simulations, also the simulations employing 1750 emissions are run for the year 2000 after a spin-up of 3 months following Stier et al. (2005). The nudging time scales are $6 \mathrm{~h}$ for vorticity, $24 \mathrm{~h}$ for the logarithms of the surface pressure and temperature and $48 \mathrm{~h}$ for the divergence.

Simulation Clim is conducted such that the global annual mean top-of-the atmosphere (TOA) radiation budget is balanced within $1 \mathrm{~W} \mathrm{~m}^{-2}$ and that the values of the shortwave and longwave cloud forcings are within the uncertainty of the cloud forcing measurements that range between -46.6 and $-50 \mathrm{~W} \mathrm{~m}^{-2}$ for the shortwave cloud forcing (Wielicki et al., 1996; Kiehl and Trenberth, 1997) and between 21.6 and $30 \mathrm{~W} \mathrm{~m}^{-2}$ for the longwave cloud forcing (Susskind 

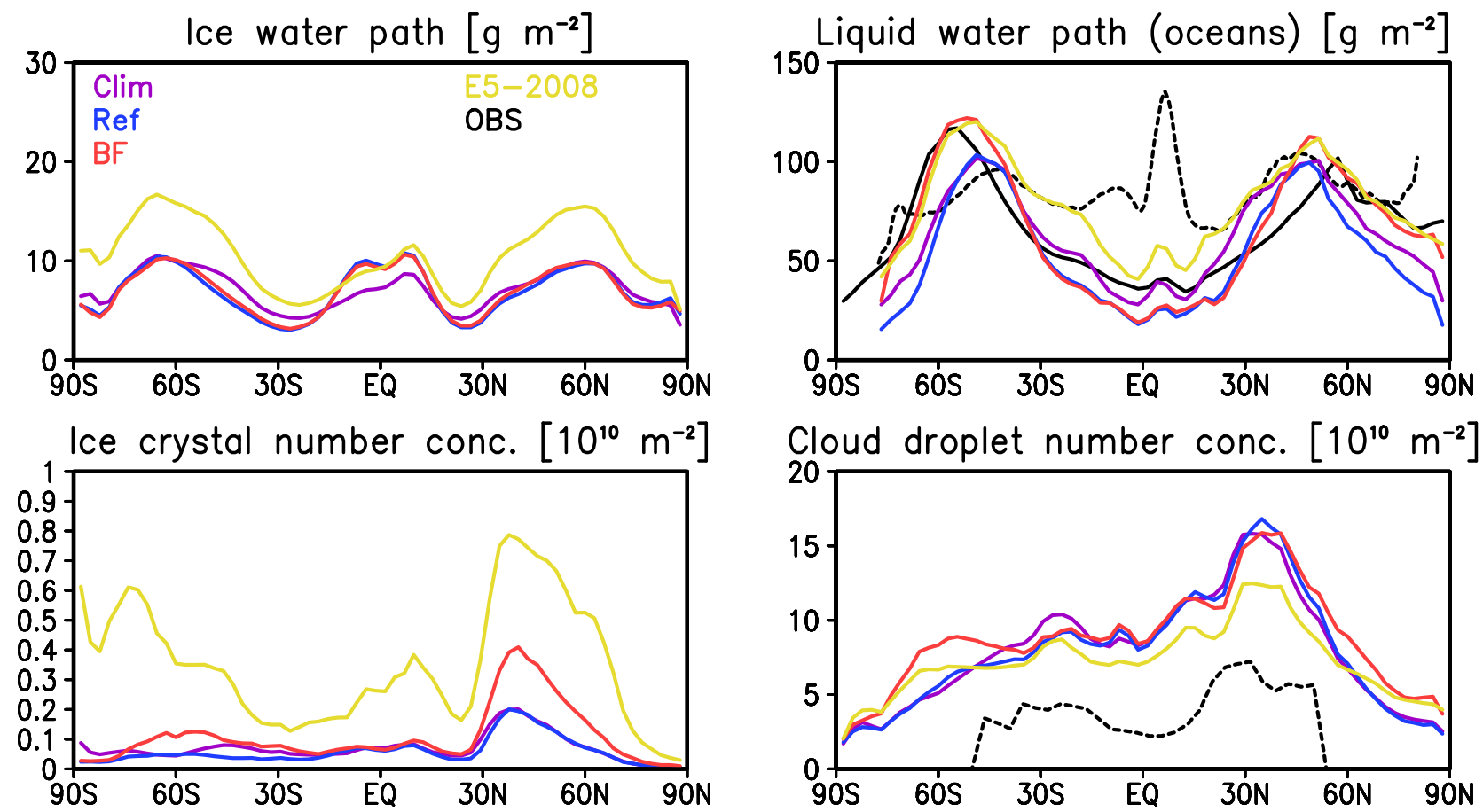

Fig. 2. Annual zonal means of the oceanic liquid water path (LWP), ice water path (IWP), vertically integrated cloud droplet number concentration $\left(N_{c}\right)$ and ice crystal number concentration from different model simulations described in Table 1. The solid black line refers to the observed LWP from MODIS. Dotted black lines refer to SSM/I data for LWP (O'Dell et al., 2008) and to ISCCP data for $N_{c}$ (Han et al., 1998).

et al., 1997; Scott et al., 1999; Kiehl and Trenberth, 1997). The present-day simulations use aerosol emissions of sulfate, black and organic carbon from the AEROCOM data base for the year 2000 (Dentener et al., 2006). Mineral dust and sea salt emissions are calculated based on wind speed within the model. To isolate the total anthropogenic aerosol effect, all simulations were repeated with aerosol emissions of sulfate, black and organic carbon for pre-industrial times representative for the year 1750 (Dentener et al., 2006). Anthropogenic dust sources are not accounted for as it is not clear how important they are (Denman et al., 2007).

We conducted various sensitivity studies as summarized in Table 1. Next to varying the importance of contact freezing of mineral dust by varying $\mathrm{SO}_{4}$-crit and the threshold for the Bergeron-Findeisen process, we investigate the importance of thermophoresis and the differences in the anthropogenic aerosol effect between climatological and nudged simulations.

\section{Comparison with observations}

Validation of the coupled aerosol-cloud microphysics scheme in stratiform clouds is described in Lohmann et al. (2007) and (2008). Since there were a few additions to the model and because we mainly focussed on the comparison of cirrus clouds in Lohmann et al. (2008), we start by repeating part of the comparison of the zonal mean cloud properties for the simulations Clim, Ref, BF and E5-2008 described in Table 1. Simulations 10lay and NoThermo are not shown as their present-day climate is very similar to that of simulation Ref. Likewise, simulation BF-10lay is not shown because of the similarity to simulation BF.

As shown in Fig. 2, the ice water path and vertically integrated ice crystal number concentration are lower in simulation Clim than in E5-2008, especially in the extratropics. This is a result of re-tuning the model such that the radiation budget is balanced again. Re-tuning was necessary because adding aerosol nucleation due to galactic cosmic rays and organic vapors, the improved below-cloud scavenging scheme and the new water uptake scheme lead to increased cloud droplet number concentrations and initially also to increased liquid water paths. After re-tuning, the liquid water path is reduced in better agreement with the observed SSM/I data in the extratropics. The peak in liquid water path in the tropics is underpredicted in all simulations, which points to deficiencies in the detrainment from convective clouds. The overestimation of the vertically integrated cloud droplet number concentration, however, remains. Note though that there are large uncertainties associated with the retrieval of vertically 

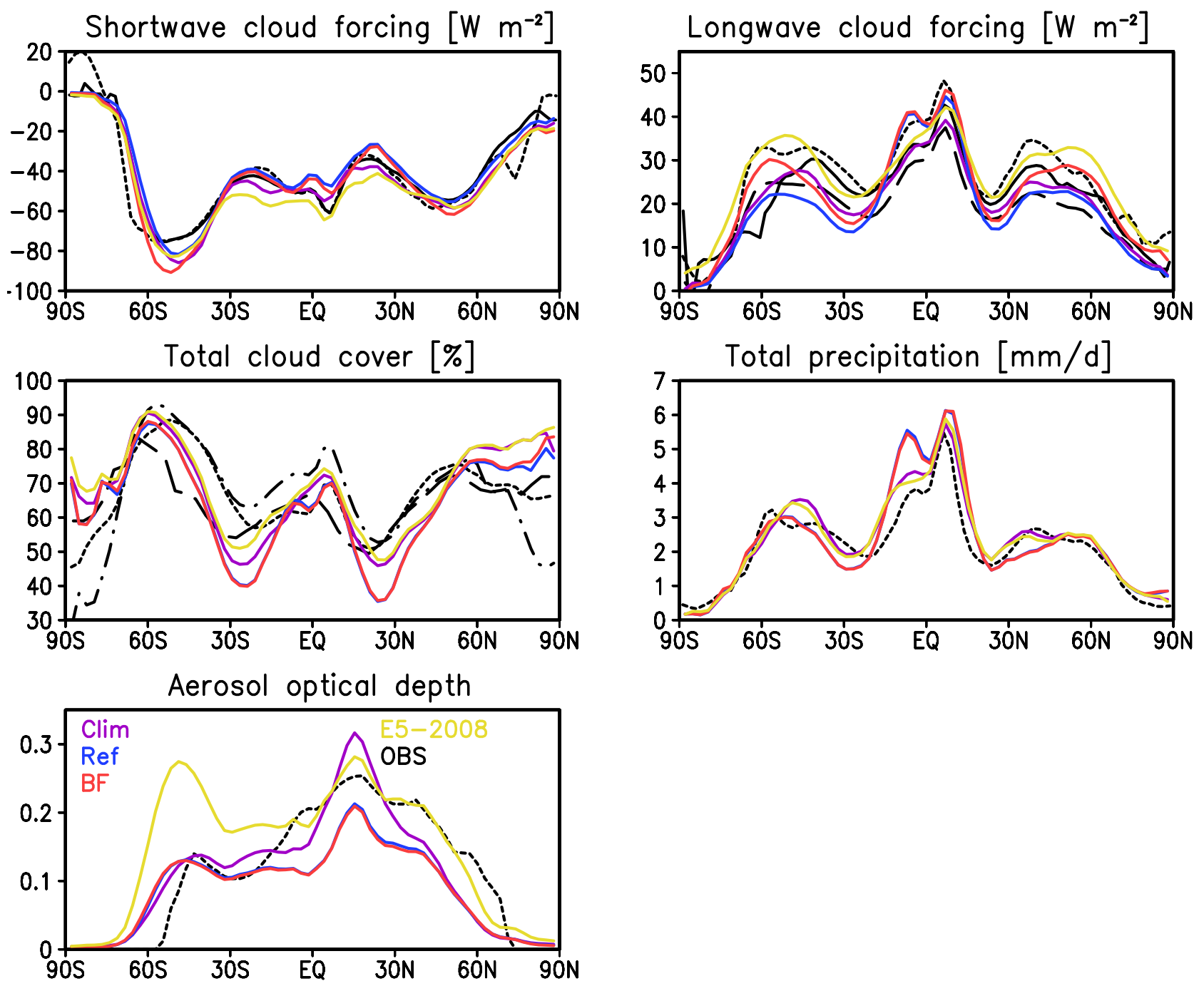

Fig. 3. As Fig. 2 but for shortwave (SCF) and longwave cloud forcing (LCF), total cloud cover, total precipitation, and aerosol optical depth (AOD). Solid lines refer to CERES data for SCF and LCF Wielicki et al. (1996). Dotted black lines refer to ISCCP data for total cloud cover, to ERBE data for the shortwave and longwave cloud forcing, to the Global Precipitation Data Set for precipitation Adler et al. (2003), and to the combined MODIS-MISR retrieval for AOD. Dashed lines refer to surface observations for total cloud cover and to TOVS data for the longwave cloud forcing (Susskind et al., 1997; Scott et al., 1999). Cloud cover from MODIS is included as the dotted-dashed line.

integrated cloud droplet number concentration and that the data refer to only a four-months average (Han et al., 1998).

The new aerosol parameterizations in simulation Clim improve the comparison of the aerosol optical depth with observations as compared to simulation E5-2008, especially over the Southern Hemisphere mid-latitudes (Fig. 3). Simulation Clim also compares better with observations than E5-2008 in terms of the shortwave cloud forcing in the subtropics and everywhere in terms of the longwave cloud forcing. The cloud forcings are less well matched in the nudged version Ref where increased convective activity leads to a higher amount of precipitation and reduced aerosol optical depth in the tropics, and to reduced cloud cover and aerosol optical depth in the subtropics.
In simulation $\mathrm{BF}$ the criterion for the Bergeron-Findeisen process is met less often (Fig. 4) as it is now more stringent by depending on $N_{i}, \overline{r_{i}}$ and the difference in saturation vapor pressure over water and ice. The less frequent Bergeron-Findeisen process in simulation BF means that less water vapor is deposited onto ice crystals, which reduces the ice water content and increases the liquid water content at altitudes where the Bergeron-Findeisen process takes place. If more liquid water remains, freezing can take place more frequently. More freezing, on the other hand, leads to an increase in the ice crystal number concentration and would mean an increase in ice water content. Thus in terms of the change in ice water content in the region affected by the Bergeron-Findeisen process the decrease in the frequency of 

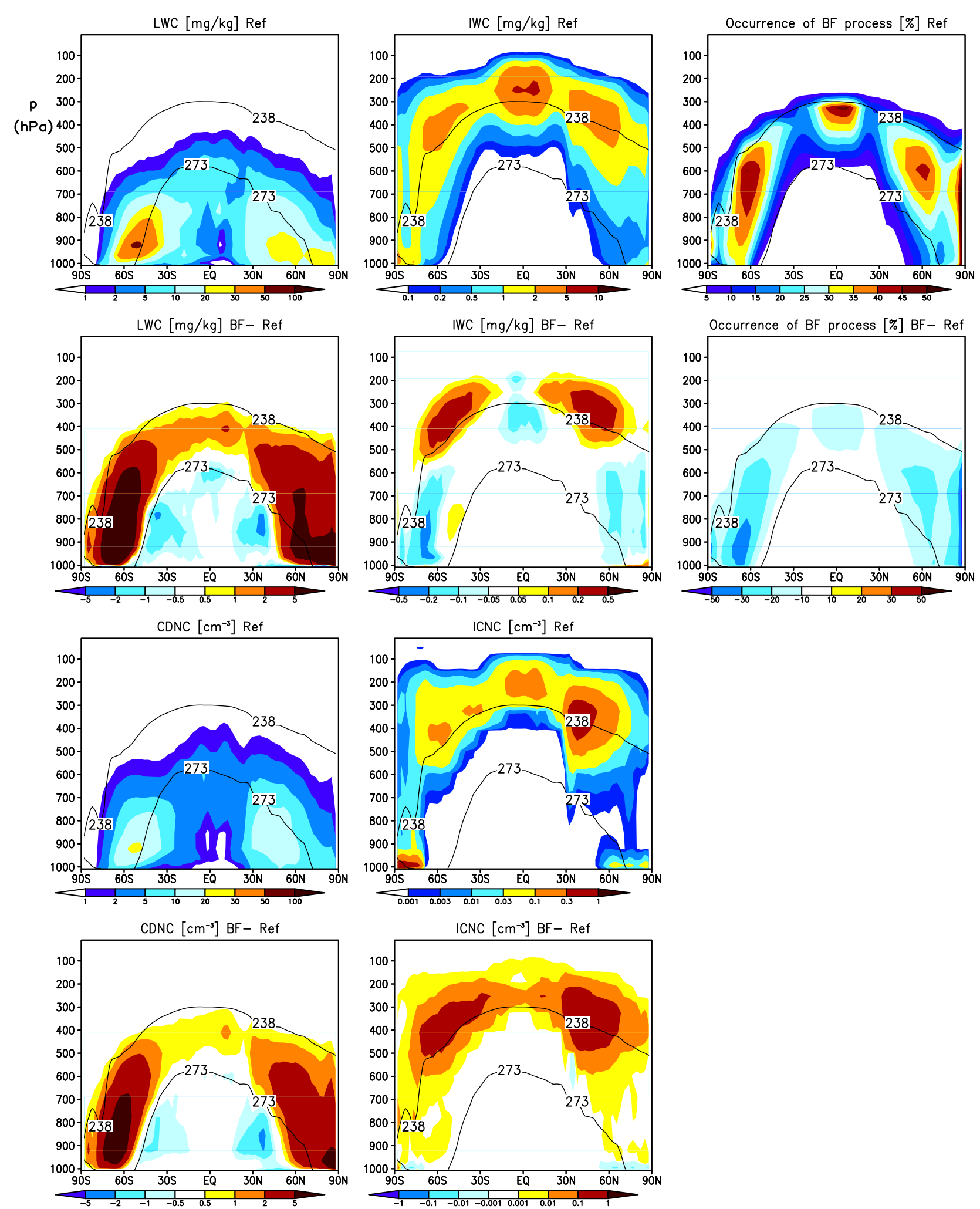

Fig. 4. Vertical zonal mean cross sections of the cloud liquid water mixing ratio (LWC), cloud ice mixing ratio (IWC), frequency of occurrence of the Bergeron-Findeisen (BF) process, cloud droplet number concentration (CDNC) and ice crystal number concentration (ICNC) for simulation Ref and for the difference between simulations BF and Ref. The $273 \mathrm{~K}$ and $238 \mathrm{~K}$ isolines are shown for reference. Note that all quantities are averages over cloudy and cloud-free regions and periods. 
the Bergeron-Findeisen process dominates over the increased freezing frequency (Fig. 4).

Above the altitudes affected by changes in the occurrence of the Bergeron-Findeisen process, the ice water content and ice crystal number increases because the less frequent Bergeron-Findeisen process extends the freezing process to higher altitudes and colder temperatures. The increase in cloud altitude and ice crystal number concentration (cf. also Fig. 2) leads to a higher longwave and shortwave cloud forcing, especially in the extratropics as compared to simulation Ref (Fig. 3).

Total cloud cover is generally well reproduced except for high latitudes where all simulations predict a higher than observed cloud amount (Fig. 3). On the contrary in the subtropics, total cloud cover is underestimated. The nudged simulations Ref and BF underpredict the subtropical cloud cover even more than the climatological simulation due to the enhanced Hadley/Walker circulation. Total precipitation is also well captured in general. Here again, the nudged simulations deviate most from the observations due to the enhanced convective precipitation in the tropics.

Figure 5 shows observed vertical profiles plus error bars of the $\mathrm{BC}$ mass mixing ratio from aircraft operating from Costa Rica in February 2006 (Schwarz et al., 2008) and from Houston, Texas in November 2004 (Schwarz et al., 2006). In addition the number fraction of internally mixed $\mathrm{BC}$ over Costa Rica is shown for BC particles between 190 and $210 \mathrm{~nm}$ in volume-equivalent diameter and the total aerosol mass over Texas. The thermal tropopause was observed to be near $100 \mathrm{hPa}$ in the tropics and near $150 \mathrm{hPa}$ in the extratropics. We selected the same data plus their $25 \%$ and $75 \%$ percentiles from the same months of the simulations in the regions that encompass the aircraft flights. We cannot obtain a number fraction of internally mixed $\mathrm{BC}$ particles for the same size range as sampled in Schwarz et al. (2008) because all the externally mixed BC particles reside in the Aitken mode, in which they are emitted (Vignati et al., 2004). This is justified as particle growth by condensation of sulfuric acid vapor or by coagulation with other particles will cause the particle to be internally mixed on the one hand and by the rather inefficient in-mode coagulation of hydrophobic particles on the other hand. We therefore assume that the coated number fraction can be obtained from the ratio of the internally mixed $\mathrm{BC}$ to the total $\mathrm{BC}$. This assumes that the mass of $\mathrm{BC}$ within the internally and externally mixed particles is of the same size. This is a fair assumption in the absence of collisions and coagulation of BC particles with themselves.

In Texas the climatological simulation and the nudged simulation are rather similar. The $\mathrm{BC}$ mass follows the total aerosol mass because the majority of all aerosols are internally mixed (Fig. 5). The simulated BC mass below $250 \mathrm{hPa}$ falls within the observed range. Above that altitude, $\mathrm{BC}$ mass is overestimated in the model. In worse agreement with observations, this overestimation is enhanced when $\mathrm{SO}_{4}$-crit is increased. If $\mathrm{SO}_{4}$-crit is set to 10 monolayers then less $\mathrm{BC}$ is removed from the atmosphere than if $\mathrm{SO}_{4}$-crit is one monolayer. While the below-cloud scavenging of internally and externally mixed aerosols in a given size class is assumed to be the same, the more important in-cloud scavenging process is less efficient for externally mixed aerosols of a given size (Stier et al., 2005). This explains the higher hydrophobic externally mixed BC concentrations in simulations 10lay and BF-10lay above $600 \mathrm{hPa}$ as compared to simulation Ref.

In Costa Rica, all simulations overestimate BC as compared to observations. Here the climatological and nudged simulations differ more. This is because nudging in the tropics causes the atmosphere to be less stable and more often invokes convection. Therefore more BC is transported into higher altitudes and less remains below $500 \mathrm{hPa}$ in simulation Ref than in simulation Clim. Qualitatively, this increase in BC between 500 and $200 \mathrm{hPa}$ agrees with the observed BC maximum at $300 \mathrm{hPa}$, but is one order of magnitude too high. The $\mathrm{BC}$ mass mixing ratio is even more overestimated when $\mathrm{SO}_{4}$-crit is increased. Here more $\mathrm{BC}$ resides in the externally mixed mode (Fig. 5) and thus is scavenged less vigorously. The smaller internally mixed fraction in simulations 10lay and BF-10lay agrees best with observations, although they also overestimate the internally mixed $\mathrm{BC}$ fraction everywhere. The slightly smaller internally mixed $\mathrm{BC}$ fractions in the mid troposphere in simulations BF and BF-10lay as compared to simulations Ref and 10lay, respectively, causes the slight increase in total BC mass (Fig. 5).

Cozic et al. (2007) analyzed the dependence of the scavenged $\mathrm{BC}$ fraction on the $\mathrm{BC}$ concentration in mixed-phase clouds at the high alpine station Jungfraujoch in Switzerland. The observations show that the scavenged $\mathrm{BC}$ fraction is smaller for larger BC concentrations. Cozic et al. (2007) suggest that this is due to the correlation of the $\mathrm{BC}$ concentration to the total aerosol number concentration. A higher aerosol number concentration and thus a larger number of cloud condensation nuclei more rapidly decrease the available supersaturation below critical levels for further activation. Therefore fewer aerosols are activated. As the aerosols at Jungfraujoch were found to be internally mixed, also less $\mathrm{BC}$ is activated.

In our comparison with these observation, we assume that all internally mixed $\mathrm{BC}$ can be activated and can reside within cloud droplets. We thus take the internally mixed BC fraction as an upper limit for the scavenged $\mathrm{BC}$ fraction. This assumption works well given that the internally mixed BC fraction in simulation Ref is similar to the observed scavenged BC fraction. Here the comparison with observations is worse when more aerosols reside in the externally mixed modes as in simulations 10lay and BF-10lay. 

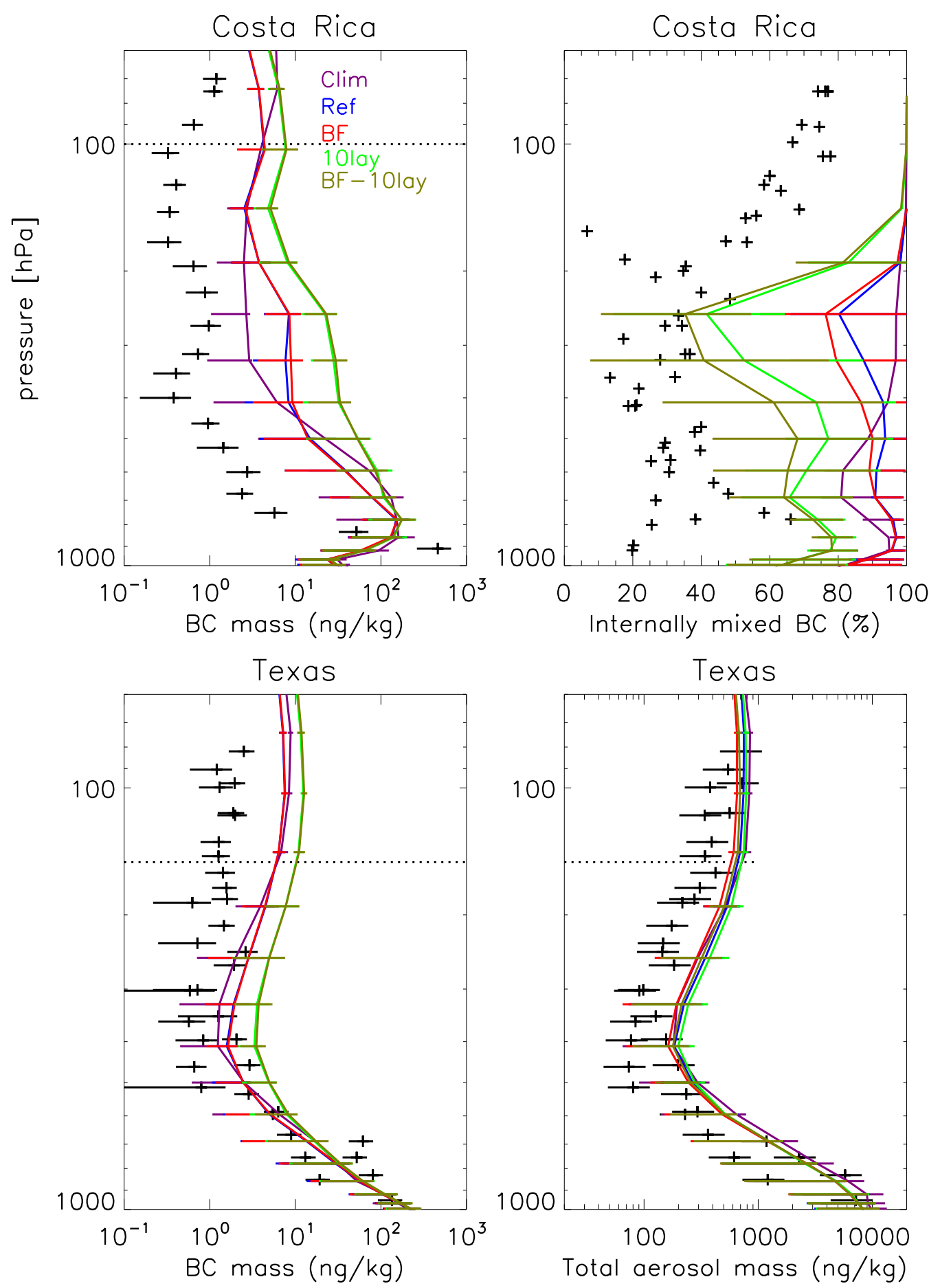

Fig. 5. Vertical profiles of the observed black carbon mass mixing ratio (crosses) as obtained from flights operating from San Jose, Costa Rica (Schwarz et al., 2008) in February 2006 (left panel) and from Houston, Texas (Schwarz et al., 2006) in November 2004 (right panel). The middle panel shows the number fraction of internally mixed BC in Costa Rica. The model results are shown as monthly means for the geographic regions that encompasses the aircraft flights (Costa Rica: $2^{\circ} \mathrm{N}-11^{\circ} \mathrm{N}$ and $80-85^{\circ} \mathrm{W}$; Texas: $29-38^{\circ} \mathrm{N}$ and $88-98^{\circ} \mathrm{W}$ ). The model variability is identified with the $25 \%$ and $75 \%$ percentiles calculated from the 12 -hourly mean concentrations. The observational data have been reproduced with courtesy of S. Schwarz. 


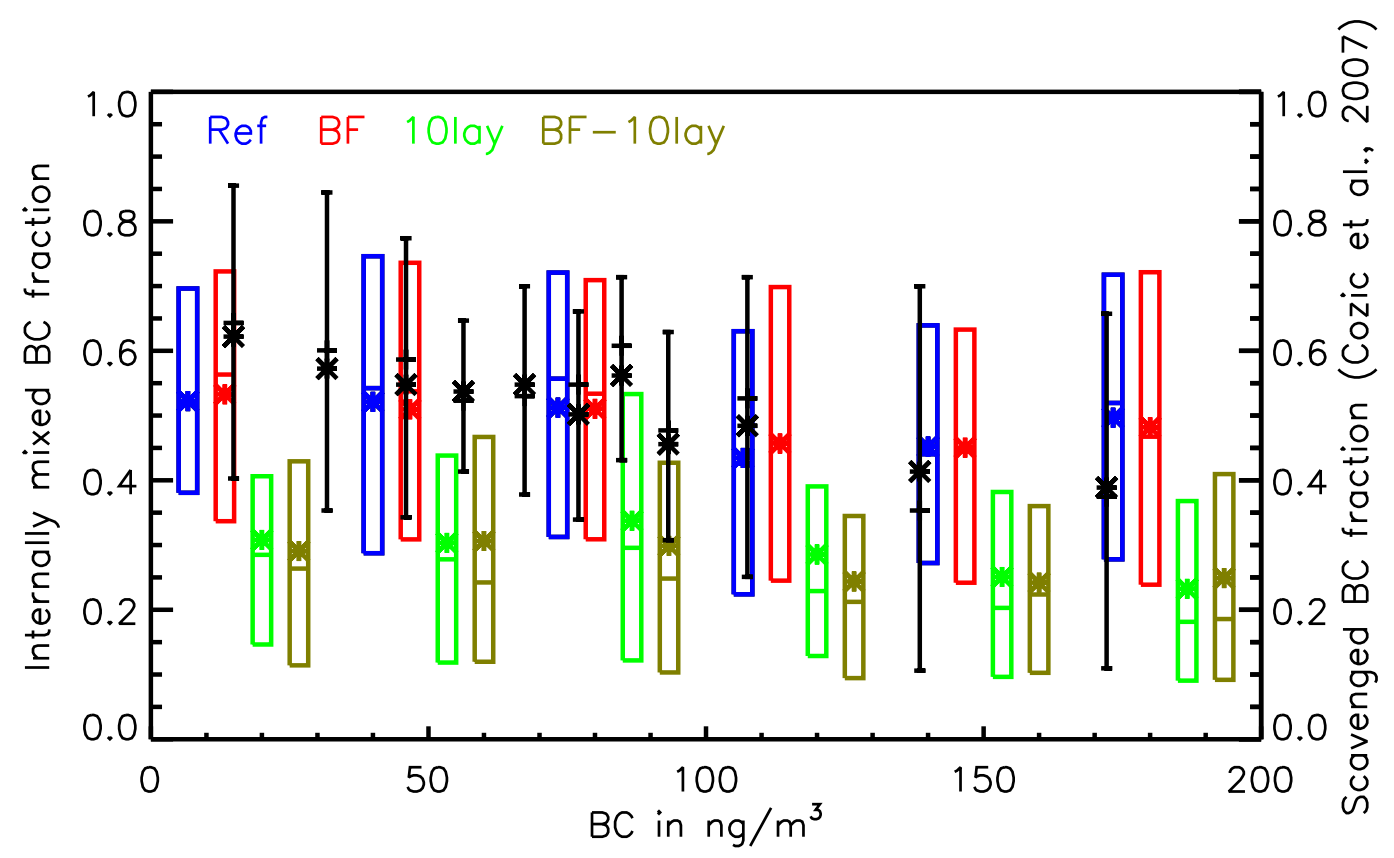

Fig. 6. Scavenged BC fraction as a function of the BC concentration in mixed-phase clouds (black symbols - right axis) as observed at the Jungfraujoch (Cozic et al., 2007). These data are obtained for warm clouds $\left(>0.5^{\circ} \mathrm{C}\right)$ and are characterized by their arithmetic mean $(*)$, median (+) and the $25 \%$ and $75 \%$ percentiles. The model results represent the internally mixed fraction and are obtained from the region $5^{\circ} \mathrm{E}-10^{\circ} \mathrm{E}, 40^{\circ} \mathrm{N}-50^{\circ} \mathrm{N}$ that encompasses the Jungfraujoch. The model variability is also identified by the arithmetic mean $(*)$, median $(+)$ and the $25 \%$ and $75 \%$ percentiles calculated from the 12 -hourly mean concentrations from one full year. The observational data have been reproduced with courtesy of J. Cozic and E. Weingartner.

\section{Impact of mixed-phase processes on the anthropogenic aerosol effect}

The changes in the externally and internally mixed BC and dust burdens (the vertically integrated mass mixing ratios) from pre-industrial to present-day times for simulations Clim, Ref, BF, 10lay and BF-10lay are shown in Fig. 7. Again, the sensitivity simulation in which thermophoresis is omitted (simulation NoThermo) is not shown as it is very similar to simulation Ref. In present-day times more sulfate is available to coat $\mathrm{BC}$ and mineral dust which explains the overall increase in internally mixed $\mathrm{BC}$ and mineral dust. The changes in externally and internally mixed BC since preindustrial times are comparable in simulations Ref and Clim, but the changes in dust burden exhibit large differences. The larger decreases in externally mixed dust and increases in internally mixed dust in simulation Clim stem from the larger dust emissions and hence a higher dust burden in the climatological simulation (Timmreck and Schulz, 2004).

When $\mathrm{SO}_{4}$-crit is increased, more externally mixed $\mathrm{BC}$ remains in the atmosphere in present-day times as compared to pre-industrial times, especially in the tropics where biomass burning dominates. The increases in internally mixed BC particles since pre-industrial times are comparable in the different sensitivity simulations because these aerosols are more efficiently removed by wet deposition than the externally mixed $\mathrm{BC}$ particles.

Because mineral dust is assumed to have no anthropogenic sources in our simulations (Stier et al., 2005), the total (external plus internal) change in mineral dust between preindustrial and present-day times is close to zero. In all simulations externally mixed dust is reduced because of coatings with anthropogenic sulfate that converts it into the internally mixed aerosol modes. In simulations 10lay and BF-10lay the least amount of externally mixed dust is converted in the internal mixed modes.

In all simulations the vertically integrated cloud droplet number and liquid water path increase most in mid latitudes over the Northern Hemisphere (Fig. 8) because of the increase in cloud lifetime due to more and smaller cloud droplets formed on the larger aerosol number concentrations in the present-day climate. As a fraction of the supercooled liquid water clouds freeze, the ice crystal number and ice water path also increase most pronounced in Northern Hemisphere mid latitudes. Note that the increase in ice crystal number and path is much smaller than the increase in cloud droplet number and liquid water path because once a supercooled cloud is glaciated, it precipitates more readily. This 

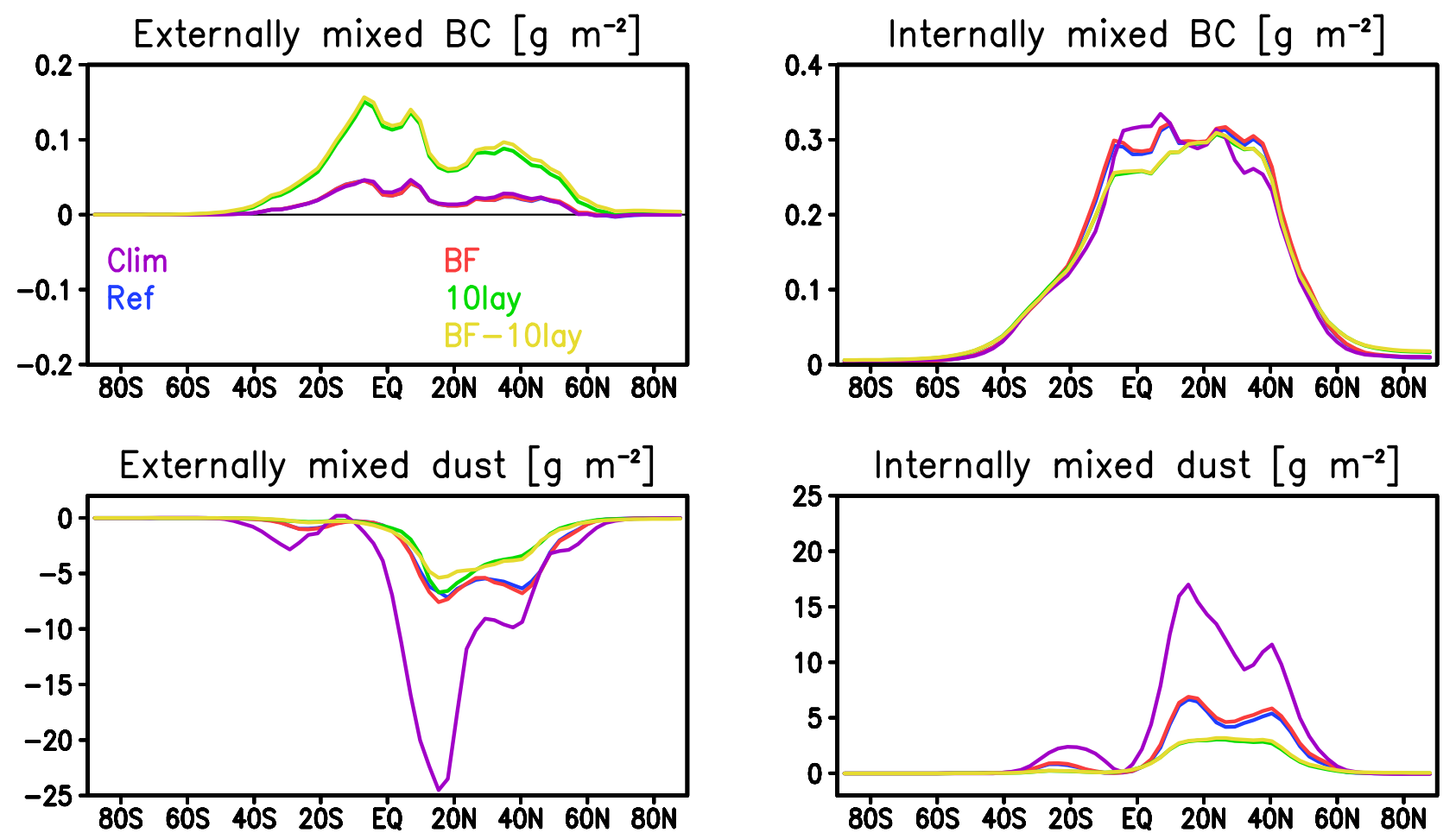

Fig. 7. Annual zonal mean changes of the externally and internally mixed BC and mineral dust burdens due to anthropogenic aerosols for simulations Clim, Ref, BF, 10lay and BF-10lay.

increase in liquid and ice water path causes an increase in total cloud cover and a reduction in TOA shortwave radiation, which amounts to between -3 and $-6 \mathrm{~W} \mathrm{~m}^{-2}$ in the Northern Hemisphere mid latitudes in the different simulations. Because of the increase in total cloud cover and ice crystal number and path more longwave radiation is trapped within the Earth-Atmosphere system, which partly counteracts the reduced shortwave radiation.

There are some differences between simulations Clim and Ref. Due to the variability in meteorology between the year 1750 and 2000 simulations, the changes in ice water path and total cloud cover are noisier in simulation Clim than in simulation Ref. As the changes in total cloud cover are directly translated into changes in outgoing longwave radiation (OLR), also the OLR exhibits larger variations. However, the change in global mean TOA net radiation is similar in simulations Ref and Clim, which justifies the use of the nudged simulations in the sensitivity studies.

Simulations 10lay and BF-10lay experience the largest number of externally mixed BC and dust particles. In turn, they also yield the largest number of mineral dust contact nuclei and thus the largest glaciation indirect aerosol effect but smallest de-activation effect. Here aerosol effects on mixedphase clouds partly offset the cloud lifetime effect on warm clouds. Subsequently the increases in cloud droplet number from pre-industrial times to the present-day are smallest in these simulations (Table 2). The differences between the sensitivity simulations in the increase in liquid and ice water path and the vertically integrated cloud droplet and ice crystal number concentration between pre-industrial and presentday times are most pronounced in the Northern Hemisphere mid-latitudes where these quantities increase the most due to anthropogenic aerosols (Fig. 8). As the increase in liquid water path determines the magnitude of the indirect aerosol effect, a smaller increase in liquid water path reduces the indirect aerosol effect.

The total anthropogenic aerosol effect is evaluated as the difference in net TOA radiation between pre-industrial and present-day times. We cannot separate between the direct, semi-direct and indirect aerosol effects because our aerosols are radiatively active and act as cloud condensation and ice nuclei. Thus, increasing aerosol concentrations since preindustrial times leads simultaneously to a direct, semi-direct and the various indirect effects. Therefore the total anthropogenic effect investigated in this paper is not a forcing in the IPCC's definition of aerosol radiative forcing because it includes feedbacks associated with these indirect aerosol effects and allows adjustments of atmospheric temperatures. However, the contributions of the direct and semidirect effect are smaller than the indirect effect in our model (Lohmann and Feichter, 2001). The total anthropogenic aerosol effect amounts to $-1.09 \mathrm{~W} \mathrm{~m}^{-2}$ in simulations Ref 

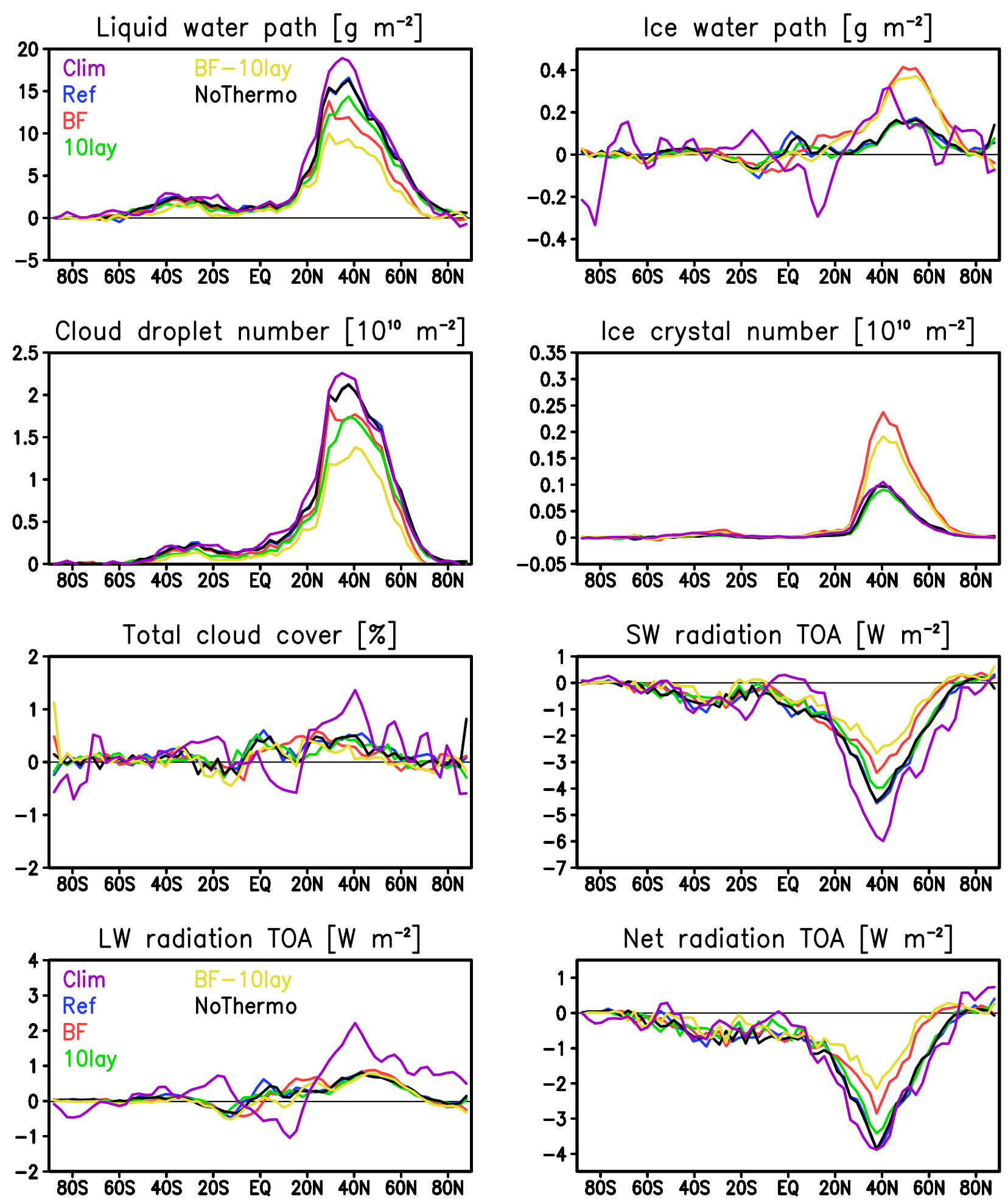

Fig. 8. Annual zonal mean changes of the liquid and ice water path, vertically integrated cloud droplet and ice crystal number concentrations, the total cloud cover, and the shortwave (SW), longwave (LW) and net radiation at the top-of-the-atmosphere due to anthropogenic aerosols for the simulations Clim, Ref, BF, 10lay, BF-10lay and NoThermo. Note that upward fluxes such as the outgoing longwave radiation are negative so that a positive deviation in outgoing longwave radiation means that less radiation is emitted to space. 
and Clim. It is thus rather independent of the meteorological conditions, i.e. if evaluated in nudged or climate mode.

The difference in the total anthropogenic aerosol effect between simulations Ref and 10lay amounts to $0.17 \mathrm{~W} \mathrm{~m}^{-2}$ in the global annual mean reflected shortwave radiation and $0.12 \mathrm{~W} \mathrm{~m}^{-2}$ in the TOA net radiation (Table 2). The total anthropogenic aerosol effect in simulation Ref is smaller than in simulation ECHAM5-strat (Lohmann, 2008) due to the changes in ice crystal shape and fall speed that were introduced in Lohmann et al. (2008). The differences between the simulations with and without thermophoresis are much smaller than the differences introduced by varying $\mathrm{SO}_{4}$-crit or the onset of the Bergeron-Findeisen process (Fig. 8 and Table 2). This suggests that the contribution of thermophoresis to contact freezing is negligible.

The largest impact on the total anthropogenic aerosol effect stems from changing the onset of the BergeronFindeisen process in agreement with the study using the CAM-Oslo GCM (Storelvmo et al., 2008b). It is reduced by 0.27 and $0.35 \mathrm{~W} \mathrm{~m}^{-2}$ in simulations BF and BF-10lay as compared to simulations Ref and 10lay, respectively. Because the Bergeron-Findeisen process occurs less frequently in simulations BF and BF10lay, supercooled cloud droplets prevail longer and heterogeneous freezing becomes more important. Thus, the glaciation effect is largest in the simulations BF and BF10lay.

Even though the glaciation effect causes more ice crystals to grow at the expense of water droplets and initiates more precipitation via the ice phase, the differences in precipitation between pre-industrial and present-day times are comparable in the different simulations. This is because the prescribed sea surface temperature largely controls the amount of evaporation and because evaporation needs to equal precipitation in the global annual mean.

\section{Conclusions}

In this paper we investigated various aerosol effects on mixed-phase clouds: The glaciation effect versus the deactivation effect. The importance of these effects is investigated by varying the parameterization for the onset of the Bergeron-Findeisen process and the threshold coating thickness of sulfate ( $\mathrm{SO}_{4}$-crit), which is required to convert an externally mixed aerosol particle into an internally mixed particle. In addition we investigated the contribution of thermophoretic contact freezing to the total contact freezing. We used the ECHAM5 GCM nudged to ECMWF ERA40 data for the year 2000 .

A comparison with observations showed that the vertical profiles over Costa Rica and Texas of the BC mass mixing ratio agree best with observations in the reference simulation Ref and in simulation BF. In these simulations only one monolayer of sulfate is required to convert externally mixed $\mathrm{BC}$ into internally mixed $\mathrm{BC}\left(\mathrm{SO}_{4}\right.$-crit). Likewise, also the comparison of the internally mixed fraction which can be regarded as the upper limit for the scavenged BC fraction is only consistent with the observed data at the Jungfraujoch in simulations Ref and $\mathrm{BF}$, but not if $\mathrm{SO}_{4}$-crit is increased to 10 monolayers as in simulations Ref-10lay and BF-10lay. On the other hand, the number fraction of internally mixed $\mathrm{BC}$ over Costa Rica is best captured in simulation BF-10lay. These contradictory results make it hard to say which simulation is the best. For that more measurements of the vertical distribution of black carbon and especially its internally versus externally mixed fraction are needed.

We showed that accounting for thermophoretic contact freezing only has a minor impact for either the presentday results or for the difference between pre-industrial and present-day times. When $\mathrm{SO}_{4}$-crit is increased, more mineral dust particles remain externally mixed and can act as contact ice nuclei. As contact ice nuclei initiate freezing at a higher temperature than immersion freezing initiated by internally mixed $\mathrm{BC}$ and dust aerosols, freezing is more efficient in simulations 10lay and BF-10lay than in simulations Ref and BF. The glaciation effect is deduced from differences between simulations 10lay and Ref and between simulations BF-10lay and BF to amount to 0.12 and $0.20 \mathrm{~W} \mathrm{~m}^{-2}$, respectively, in the global annual mean.

The glaciation effect is most pronounced when the onset of the Bergeron-Findeisen process considers the combination of the difference in saturation vapor pressure between water and ice, the ice crystal number concentration and ice crystal size (Eq. 5) instead of just a fixed threshold in the cloud ice mixing ratio. The more physical treatment of the Bergeron-Findeisen process leads to less frequent glaciation of supercooled clouds. Thus, the lifetime of the supercooled cloud droplets is increased, so that heterogeneous freezing is more important in the BF simulations as compared to simulation Ref. This yields a 0.27 and $0.35 \mathrm{~W} \mathrm{~m}^{-2}$ less negative total anthropogenic aerosol effect (Table 2). Combined with varying $\mathrm{SO}_{4}$-crit, the anthropogenic aerosol effect varies up to $0.47 \mathrm{~W} \mathrm{~m}^{-2}$ between the different simulations.

It is not possible to constrain which scenario is the best as all of the total anthropogenic aerosol effect estimates are well within the range estimated from inverse measurements (Hegerl et al., 2007) and from an energy balance perspective (Murphy et al., 2009). However, the revised BergeronFindeisen process is clearly preferred over the original one as initiating glaciation beyond a critical ice water mixing ratio independent of temperature and updraft velocity is clearly a simplification. One uncertainty that remains with the revised Bergeron-Findeisen process is if our updraft velocity, even though it takes subgrid-scale velocity fluctuations into account, is representative for typical velocities at cloud base.

A shortcoming of this study is that we do not calculate aerosol activation based upon supersaturation and Köhler theory such as done in the parameterizations of AbdulRazzak and Ghan (2002) and Nenes and Seinfeld (2003). This is work in progress and will be available in future. 
Table 2. Global annual mean changes in liquid (LWP) and ice water path (IWP), vertically integrated cloud droplet ( $\left.N_{l}\right)$ and ice crystal number concentration $\left(N_{i}\right)$, precipitation and the shortwave, longwave and net radiation at the top-of-the-atmosphere due to anthropogenic aerosols. Note that upward fluxes are negative so that a positive deviation in outgoing longwave radiation means that less radiation is emitted to space.

\begin{tabular}{lrrrrrr}
\hline Simulation & Clim & Ref & BF & 10lay & NoThermo & BF-10lay \\
\hline$\Delta \mathrm{LWP}_{\mathrm{g} \mathrm{m}} \mathrm{g}^{-2}$ & 5.0 & 4.4 & 3.5 & 3.7 & 4.4 & 2.5 \\
$\Delta N_{l}, 10^{10} \mathrm{~m}^{-2}$ & 0.60 & 0.56 & 0.47 & 0.43 & 0.56 & 0.32 \\
$\Delta \mathrm{IWP}_{\mathrm{g} \mathrm{m}}^{-2}$ & 0.028 & 0.025 & 0.066 & 0.019 & 0.026 & 0.053 \\
$\Delta N_{i}, 10^{10} \mathrm{~m}^{-2}$ & 0.018 & 0.015 & 0.038 & 0.014 & 0.015 & 0.031 \\
$\Delta{\text { Precipitation, } \mathrm{mm} \mathrm{d}^{-1}}^{-0.015}$ & -0.016 & -0.017 & -0.018 & -0.016 & -0.018 \\
$\Delta \mathrm{SW}$ radiation, $\mathrm{W} \mathrm{m}^{-2}$ & -1.47 & -1.3 & -1.00 & -1.13 & -1.29 & -0.72 \\
$\Delta \mathrm{LW}$ radiation, $\mathrm{W} \mathrm{m}^{-2}$ & 0.37 & 0.21 & 0.18 & 0.17 & 0.17 & 0.10 \\
$\Delta$ Net radiation, $\mathrm{W} \mathrm{m}^{-2}$ & -1.09 & -1.09 & -0.82 & -0.97 & -1.12 & -0.62 \\
\hline
\end{tabular}

This scheme will then be coupled to the aerosol processing scheme by Hoose et al. (2008a) that keeps track of the number and mass mixing ratios of aerosol particles within cloud droplets and ice crystals. Once such an activation scheme is available, particles with sufficient sulfate coating can automatically be activated into cloud droplets and will thus automatically be available as immersion nuclei.

Ice nucleation parameterizations for GCMs (such as the semi-empirical parameterization by Diehl et al., 2006 or the formulation of classical nucleation theory by Chen et al., 2008) are based on parameters for the different freezing modes and IN which need to be derived from laboratory experiments. Here new data for immersion freezing show the importance of accounting for active sites in order to understand laboratory data of immersion freezing (Marcolli et al., 2007). A parameterization for immersion freezing based on active sites has been developed for certain mineral dusts (Connolly et al., 2009). If these same dust particles were also investigated in contact nucleation mode, we would then be able to complement the wind tunnel studies that entered the parameterization by Diehl et al. (2006). While the data used in Diehl et al. (2006) are mostly consistent between contact and immersion freezing, the drops used in the wind tunnel studies were of drizzle drop size rather than cloud droplets. Applying them to cloud droplets may not be appropriate. Therefore, new laboratory studies on contact and immersion freezing with realistic cloud droplet sizes for mineral dust and black carbon particles are necessary. Data in different freezing modes should be obtained for the same IN so that the data are comparable. Since contact nucleation depends crucially on the collision rates between cloud droplets and aerosol particles, collision rates need to be reported as well.

Acknowledgements. The authors thank Shuka Schwarz, Stefan Kinne, Johannes Quaas and Kai Zhang for providing the observational data used in this study and Sylvaine Ferrachat for technical help. We thank Paul DeMott, Philip Stier, Hans Feichter, Jan Kazil, Stephanie Jess and one anonymous referee for useful comments and discussions. We acknowledge funding from EUCAARI (European Integrated project on Aerosol Cloud Climate and Air Quality interactions) No 036833-2 and NCCR Climate and thank CSCS for computing time.

Edited by: M. Kulmala

\section{References}

Abdul-Razzak, H. and Ghan, S. J.: A parameterization of aerosol activation: 3. Sectional representation, J. Geophys. Res., 107, 4026, doi:10.1029/2001JD000 483, 2002.

Ackerman, A. S., Kirkpatrick, M. P., Stevens, D. E., and Toon, O. B.: The impact of humidity above stratiform clouds on indirect climate forcing, Nature, 432, 1014-1017, 2004.

Adler, R. F., Huffman, G. J., Chang, A., Ferraro, R., Xie, P. P., Janowiak, J., Rudolf, B., Schneider, U., Curtis, S., Bolvin, D., Gruber, A., Susskind, J., Arkin, P., and Nelkin, E.: The version2 global precipitation climatology project (GPCP) monthly precipitation analysis (1979-present), J. Hydrometeorol., 4, 11471167, 2003.

Baker, M. B. and Peter, T.: Small-scale cloud processes and climate, Nature, 451, 299-300, 2008.

Brinkop, S. and Roeckner, E.: Sensitivity of a general circulation model to parameterizations of cloud-turbulence interactions in the atmospheric boundary layer, Tellus, A, 47, 197-220, 1995.

Chen, J.-P., Hazra, A., and Levin, Z.: Parameterizing ice nucleation rates using contact angle and activation energy derived from laboratory data, Atmos. Chem. Phys., 8, 7431-7449, 2008, http://www.atmos-chem-phys.net/8/7431/2008/.

Connolly, P. J., Möhler, O., Field, P. R., Saathoff, H., Burgess, R., Choularton, T., and Gallagher, M.: Studies of heterogeneous freezing by three different desert dust samples, Atmos. Chem. Phys., 9, 2805-2824, 2009, http://www.atmos-chem-phys.net/9/2805/2009/.

Cotton, W. R., Tripoli, G. J., Rauber, R. M., and Mulvihill, E. A.: Numerical Simulation of the Effects of Varying Ice Crystal Nucleation Rates and Aggregation Processes on Orographic Snowfall, J. Clim. Appl. Meteorol., 25, 1658-1680, 1986. 
Cozic, J., Verheggen, B., Mertes, S., Connolly, P., Bower, K., Petzold, A., Baltensperger, U., and Weingartner, E.: Scavenging of black carbon in mixed phase clouds at the high alpine site Jungfraujoch, Atmos. Chem. Phys., 7, 1797-1807, 2007, http://www.atmos-chem-phys.net/7/1797/2007/.

Croft, B., Lohmann, U., Martin, R. V., Stier, P., Wurzler, S., Feichter, J., Posselt, R., and Ferrachat, S.: Aerosol size-dependent below-cloud scavenging by rain and snow in the ECHAM5HAM, Atmos. Chem. Phys., 9, 4653-4675, 2009,

http://www.atmos-chem-phys.net/9/4653/2009/.

Denman, K., Brasseur, G., Chidthaisong, A., Ciais, P., Cox, P., Dickinson, R., Hauglustaine, D., Heinze, C., Holland, E., Jacob, D., Lohmann, U., Ramachandran, S., Silva Dias, P., Wofsy, S., and Zhang, X.: Couplings between changes in the climate system and biogeochemistry, in: Climate Change 2007: The Physical Science Basis, Contribution of Working Group I to the Fourth Assessment Report of the Intergovernmental Panel on Climate Change, edited by: Solomon, S., Qin, D., Manning, M., Chen, Z., Marquis, M., Averyt, K. B., Tignor, M., and Miller, H. L., Cambridge Univ. Press, Cambridge, UK and New York, NY, USA, 499-588, 2007.

Dentener, F., Kinne, S., Bond, T., Boucher, O., Cofala, J., Generoso, S., Ginoux, P., Gong, S., Hoelzemann, J. J., Ito, A., Marelli, L., Penner, J. E., Putaud, J.-P., Textor, C., Schulz, M., van der Werf, G. R., and Wilson, J.: Emissions of primary aerosol and precursor gases in the years 2000 and 1750 prescribed data-sets for AeroCom, Atmos. Chem. Phys., 6, 4321-4344, 2006, http://www.atmos-chem-phys.net/6/4321/2006/.

Diehl, K., Simmel, M., and Wurzler, S.: Numerical simulations on the impact of aerosol properties and freezing modes on the glaciation, microphysics, and dynamics of convective clouds, J. Geophys. Res., 111, D07202, doi:10.1029/2005JD005 884, 2006.

Eastwood, M. L., Cremel, S., Wheeler, M., Murray, B. J., Girard, E., and Bertram, A. K.: Effects of sulfuric acid and ammonium sulfate coatings on the ice nucleation properties of kaolinite particles, Geophys. Res. Lett., 36, L02811, doi:10.1029/2008GL035 997, 2009.

Field, P. R., Möhler, O., Connolly, P., Krämer, M., Cotton, R., Heymsfield, A. J., Saathoff, H., and Schnaiter, M.: Some ice nucleation characteristics of Asian and Saharan desert dust, Atmos. Chem. Phys., 6, 2991-3006, 2006,

http://www.atmos-chem-phys.net/6/2991/2006/.

Forster, P., Ramaswamy, V., Artaxo, P., Berntsen, T., Betts, R., Fahey, D. W., Haywood, J., Lean, J., Lowe, D. C., Myhre, G., Nganga, J., Prinn, R., Raga, G., Schulz, M., and Van Dorland, R.: Radiative Forcing of Climate Change, in: Climate Change 2007: The Physical Science Basis, Contribution of Working Group I to the Fourth Assessment Report of the Intergovernmental Panel on Climate Change, edited by: Solomon, S., Qin, D., Manning, M., Chen, Z., Marquis, M., Averyt, K. B., Tignor, M., and Miller, H. L., Cambridge Univ. Press, Cambridge, UK and New York, NY, USA, 129-234, 2007.

Girard, E., Blanchet, J.-P., and Dubois, Y.: Effects of arctic sulphuric acid aerosols on wintertime low-level atmospheric ice crystals, humidity and temperature at Alert, Nunavut, Atmos. Res., 73, 131-148, 2004.

Han, Q., Rossow, W. B., Chou, J., and Welch, R.: Global Variation of column droplet concentration in low-level clouds, Geophys.
Res. Lett., 25, 1419-1422, 1998.

Hansen, J., Sato, M., and Ruedy, R.: Radiative forcing and climate response, J. Geophys. Res., 102, 6831-6864, 1997.

Hegerl, G. C., Zwiers, F. W., Braconnot, P., Gillett, N. P., Luo, Y., Orsini, J. A. M., Nicholls, N., Penner, J. E., and Stott, P. A.: Understanding and attributing climate change, in: Climate Change 2007: The Physical Science Basis. Contribution of Working Group I to the Fourth Assessment Report of the Intergovernmental Panel on Climate Change, edited by: Solomon, S., Qin, D., Manning, M., Chen, Z., Marquis, M., Averyt, K. B., Tignor, M., and Miller, H. L., Cambridge Univ. Press, Cambridge, UK and New York, NY, USA, 663-746, 2007.

Hoose, C., Lohmann, U., Stier, P., Verheggen, B., and Weingartner, E.: Aerosol processing in mixed-phase clouds in ECHAM5HAM: Model description and comparison to observations, J. Geophys. Res., 113, D07210, doi:10.1029/2007JD009251, 2008a.

Hoose, C., Lohmann, U., Erdin, R., and Tegen, I.: Global influence of dust mineralogical composition on heterogeneous ice nucleation in mixed-phase clouds, Environ. Res. Lett., 3, 025003, doi:10.1088/1748-9326/3/2/025 003, 2008b.

Kärcher, B. and Ström, J.: The roles of dynamical variability and aerosols in cirrus cloud formation, Atmos. Chem. Phys., 3, 823838, 2003,

http://www.atmos-chem-phys.net/3/823/2003/.

Kazil, J. and Lovejoy, E. R.: A semi-analytical method for calculating rates of new sulfate aerosol formation from the gas phase, Atmos. Chem. Phys., 7, 3447-3459, 2007, http://www.atmos-chem-phys.net/7/3447/2007/.

Kiehl, J. T. and Trenberth, K. E.: Earth's Annual Global Mean Energy Budget, B. Am. Meteorol. Soc., 78, 197-208, 1997.

Korolev, A.: Limitations of the Wegener-Bergeron-Findeisen mechanism in the evolution of mixed-phase clouds, J. Atmos. Sci., 64, 3372-3375, 2007.

Korolev, A. V. and Mazin, I. P.: Supersaturation of water vapor in clouds, J. Atmos. Sci., 60, 2957-2974, 2003.

Kulmala, M., Lehtinen, K. E. J., and Laaksonen, A.: Cluster activation theory as an explanation of the linear dependence between formation rate of $3 \mathrm{~nm}$ particles and sulphuric acid concentration, Atmos. Chem. Phys., 6, 787-793, 2006, http://www.atmos-chem-phys.net/6/787/2006/.

Lohmann, U.: A glaciation indirect aerosol effect caused by soot aerosols, Geophys. Res. Lett., 29, 1052, doi:10.1029/2001GL014 357, 2002.

Lohmann, U.: Global anthropogenic aerosol effects on convective clouds in ECHAM5-HAM, Atmos. Chem. Phys., 8, 2115-2131, 2008, http://www.atmos-chem-phys.net/8/2115/2008/.

Lohmann, U. and Diehl, K.: Sensitivity studies of the importance of dust ice nuclei for the indirect aerosol effect on stratiform mixedphase clouds, J. Atmos. Sci, 63, 968-982, 2006.

Lohmann, U. and Feichter, J.: Can the direct and semi-direct aerosol effect compete with the indirect effect on a global scale?, Geophys. Res. Lett., 28, 159-161, 2001.

Lohmann, U. and Feichter, J.: Global indirect aerosol effects: a review, Atmos. Chem. Phys., 5, 715-737, 2005, http://www.atmos-chem-phys.net/5/715/2005/.

Lohmann, U. and Roeckner, E.: Design and performance of a new cloud microphysics scheme developed for the ECHAM general 
circulation model, Clim. Dynam., 12, 557-572, 1996.

Lohmann, U., Feichter, J., Chuang, C. C., and Penner, J. E.: Predicting the number of cloud droplets in the ECHAM GCM, J. Geophys. Res., 104, 9169-9198, 1999.

Lohmann, U., Stier, P., Hoose, C., Ferrachat, S., Kloster, S., Roeckner, E., and Zhang, J.: Cloud microphysics and aerosol indirect effects in the global climate model ECHAM5-HAM, Atmos. Chem. Phys., 7, 3425-3446, 2007, http://www.atmos-chem-phys.net/7/3425/2007/.

Lohmann, U., Spichtinger, P., Jess, S., Peter, T., and Smit, H.: Cirrus cloud formation and ice supersaturated regions in a global climate model, Environ. Res. Lett., 3, 045022, doi:10.1088/1748-9326/3/4/045 022, 2008.

Marcolli, C., Gedamke, S., Peter, T., and Zobrist, B.: Efficiency of immersion mode ice nucleation on surrogates of mineral dust, Atmos. Chem. Phys., 7, 5081-5091, 2007, http://www.atmos-chem-phys.net/7/5081/2007/.

Murphy, D. M., Solomon, S., Portmann, R. W., Rosenlof, K. H., Forster, P. M. D. F., and Wong, T.: An observationally based energy balance for the Earth since 1950, J. Geophys. Res., 114, D17107, doi:10.1029/2009JD012 105, 2009.

Nenes, A. and Seinfeld, J. H.: Parameterization of cloud droplet formation in global climate models, J. Geophys. Res., 108, 4415, doi:10.1029/2002JD002 911, 2003.

Niedermeier, D., Hartmann, S., Shaw, R. A., Covert, D., Mentel, T. F., Schneider, J., Poulain, L., Reitz, P., Spindler, C., Clauss, T., Kiselev, A., Hallbauer, E., Wex, H., Mildenberger, K., and Stratmann, F.: Heterogeneous freezing of droplets with immersed mineral dust particles - measurements and parameterization, Atmos. Chem. Phys. Discuss., 9, 15827-15865, 2009, http://www.atmos-chem-phys-discuss.net/9/15827/2009/.

O'Brien, K.: The theory of cosmic-ray and high-energy solarparticle transport in the atmosphere, in: The natural radiation environment VII, edited by: McLaughlin, J. P., Simopoulos, E. S., and Steinhäusler, F., seventh International Symposium on the Natural Radiation Environment, Elsevier, 2005.

O'Dell, C. W., Wentz, F. J., and Bennartz, R.: Cloud liquid water path from satellite-based passive microwave observations: A new climatology over the global oceans, J. Climate, 21, 1721-1739, 2008.

Petters, M. D. and Kreidenweis, S. M.: A single parameter representation of hygroscopic growth and cloud condensation nucleus activity, Atmos. Chem. Phys., 7, 1961-1971, 2007, http://www.atmos-chem-phys.net/7/1961/2007/.

Phillips, V. T. J., Donner, L. J., and Garner, S. T.: Nucleation processes in deep convection simulated by a cloud-system-resolving model with double-moment bulk microphysics, J. Atmos. Sci., 64, 738-761, 2007.

Phillips, V. T. J., DeMott, P. J., and Andronache, C.: An empirical parameterization of heterogeneous ice nucleation for multiple chemical species of aerosol, J. Atmos. Sci., 65, 2757-2783, 2008.

Pruppacher, H. R. and Klett, J. D.: Microphysics of Clouds and Precipitation, Kluwer Acad., Norwell, Mass., 1997.

Ramanathan, V., Crutzen, P. J., Kiehl, J. T., and Rosenfeld, D.: Aerosols, climate and the hydrological cycle, Science, 294, 2119-2124, 2001.

Roeckner, E., Bäuml, G., Bonaventura, L., Brokopf, R., Esch, M., Giorgetta, M., Hagemann, S., Kirchner, I., Kornblueh,
L., Manzini, E., Rhodin, A., Schlese, U., Schulzweida, U., and Tompkins, A.: The atmospheric general circulation model ECHAM5, Part I: Model description, Max-Planck-Inst. für Meteorol., Hamburg, Germany, Tech. Rep., 349, 2003.

Rogers, R. R. and Yau, M. K.: A Short Course in Cloud Physics, Pergamon, Tarrytown, N. Y., 1989.

Salam, A., Lesins, G., and Lohmann, U.: Laboratory study of heterogeneous ice nucleation in deposition mode of montmorillonite mineral dust particles aged with ammonia, sulfur dioxide, and ozone at polluted atmospheric concentrations, Air Qual. Atmos. Health, 1, 135-142, 2008.

Sandu, I., Brenguier, J. L., Geoffroy, O., Thouron, O., and Masson, V.: Aerosol impacts on the diurnal cycle of marine stratocumulus, J. Atmos. Sci., 65, 2705-2718, 2008.

Schwarz, J. P., Gao, R. S., Fahey, D. W., Thomson, D. S., Watts, L. A., Wilson, J. C., Reeves, J. M., Darbeheshti, M., Baumgardner, D. G., Kok, G. L., Chung, S. H., Schulz, M., Hendricks, J., Lauer, A., Karcher, B., Slowik, J. G., Rosenlof, K. H., Thompson, T. L., Langford, A. O., Loewenstein, M., and Aikin, K. C.: Single-particle measurements of midlatitude black carbon and light-scattering aerosols from the boundary layer to the lower stratosphere, J. Geophys. Res., 111, D16207, doi:10.1029/2006JD007 076, 2006.

Schwarz, J. P., Spackman, J. R., Fahey, D. W., Gao, R. S., Lohmann, U., Stier, P., Watts, L. A., Thomson, D. S., Lack, D. A., Pfister, L., Mahoney, M. J., Baumgardner, D., Wilson, J. C., and Reeves, J. M.: Coatings and their enhancement of black carbon light absorption in the tropical atmosphere, J. Geophys. Res., 113, D03203, doi:10.1029/2007JD009 042, 2008.

Scott, N. A., Chedin, A., Armante, R., Francis, J., Stubenrauch, C., Chaboureau, J. P., Chevallier, F., Claud, C., and Cheruy, F.: Characteristics of the TOVS Pathfinder Path-B dataset, B. Am. Meteorol. Soc., 80, 2679-2701, 1999.

Seinfeld, J. H. and Pandis, S. N.: Atmospheric chemistry and physics: From air pollution to climate change, Wiley, 1997.

Shaw, R. A., Durant, A. J., and Mi, Y.: Heterogeneous Surface Crystallization Observed in Undercooled Water, J. Phys. Chem. B, 109, 9865-9868, 2005.

Simmons, A. J. and Gibson, J. K.: The ERA-40 project plan, Tech. Rep., ECMWF, Shinfield Park, Reading, UK, 2000.

Stier, P., Feichter, J., Kinne, S., Kloster, S., Vignati, E., Wilson, J., Ganzeveld, L., Tegen, I., Werner, M., Balkanski, Y., Schulz, M., Boucher, O., Minikin, A., and Petzold, A.: The aerosolclimate model ECHAM5-HAM, Atmos. Chem. Phys., 5, 1125 1156, 2005, http://www.atmos-chem-phys.net/5/1125/2005/.

Storelvmo, T., Kristjánsson, J.-E., and Lohmann, U.: Aerosol influence on mixed-phase clouds in CAM-Oslo, J. Atmos. Sci., 65, 3214-3230, 2008a.

Storelvmo, T., Kristjánsson, J. E., Lohmann, U., Iversen, T., Kirkevåg, A., and Seland, Ø.: Modeling of the WegenerBergeron-Findeisen process - implications for aerosol indirect effects, Environ. Res. Lett., 3, 045001, doi:10.1088/17489326/3/4/045 001, 2008b.

Sundqvist, H., Berge, E., and Kristjánsson, J. E.: Condensation and Cloud Parameterization Studies with a Mesoscale Numerical Weather Prediction Model, Mon. Weather Rev., 117, 1641-1657, 1989.

Susskind, J., Piraino, P., Rokke, L., Iredell, T., and Mehta, A.: Char- 
acteristics of the TOVS Pathfinder Path A dataset, B. Am. Meteorol. Soc., 78, 1449-1472, 1997.

Timmreck, C. and Schulz, M.: Significant dust simulation differences in nudged and climatological operation mode of the AGCM ECHAM, J. Geophys. Res., 109, D13202, 2004.

Vignati, E., Wilson, J., and Stier, P.: An efficient sizeresolved aerosol microphysics module for large-scale aerosol transport models, J. Geophys. Res, 109, D22202, doi:10.1029/2003JD004 485, 2004.
Welti, A., Lüönd, F., Stetzer, O., and Lohmann, U.: Influence of particle size on the ice nucleating ability of mineral dusts, Atmos. Chem. Phys., 9, 6705-6715, 2009, http://www.atmos-chem-phys.net/9/6705/2009/.

Wielicki, B. A., Barkstrom, B. R., Harrison, E. F., Lee, R. B., Smith, G. L., and Cooper, J. E.: Clouds and the earth's radiant energy system (CERES): An earth observing system experiment, B. Am. Meteorol. Soc., 77, 853-868, 1996. 